\title{
COMPOSITION, MICROSTRUCTURE AND RHX DATING OF ROMANESQUE RELIEF CERAMIC TILES
}

\author{
\#ALEXANDRA KLOUŽKOVÁ*, MÁRIA KAVANOVÁ*, MARTINA KOHOUTKOVÁ**, \\ PETRA ZEMENOVÁ*, MICHAL TRYML***, PAVLA DVOŘÁKOVÁ* \\ *Department of Glass and Ceramics, University of Chemistry and Technology Prague, \\ Technická 5, 16628 Prague, Czech Republic \\ **Central laboratories, University of Chemistry and Technology Prague, \\ Technická 5, Prague, 166 28, Czech Republic \\ ***National Heritage Institute, Na Perštýně 12, 11000 Prague, Czech Republic \\ \#E-mail: alexandra.klouzkova@vscht.cz
}

Submitted May 7, 2017; accepted June 27, 2017

\begin{abstract}
Keywords: Terracotta tiles, Microstructure, X-ray techniques, Thermal analysis, Dating, Rehydroxylation
Fragments of Romanesque relief terracotta tiles were found during archaeological research in Prague, the Czech Republic. The finding represents part of the floor in an Early Romanesque rotunda. The aim of this work was to evaluate the microstructure and ageing process and to consider the possibility of the preparation of these tiles by using local raw materials. Thermal analysis was used to characterise the fine fractions of samples. The chemical and mineralogical composition of the tiles and surface decoration were compared and discussed. The application of the rehydroxylation (RHX) dating method was studied. It was proven that the differences in the ceramic body phase composition of the tiles were caused by variable firing temperatures. The results indicate that the tiles were imported and not produced from local raw materials.
\end{abstract}

\section{INTRODUCTION}

Romanesque relief ceramic tiles are known to be used in floor decoration of sacred architecture. They were made of iconographic themes and symbols of the lowest significant stage due to their location and function in sacral places. Romanesque terracotta tiles were inspired by older Italian stone or marble floors (Lombardy). Similar decorations of floor tiles can be seen in French and Alsatian Benedictine monasteries (e.g., the Benedictine abbey of Frauenwörth). The iconographic relief terracotta tiles, which were found during several archaeological research works in the Czech territory which belong to the Christian Romanesque artwork of Western Europe. In the Early Middle Ages (in the $12^{\text {th }}$ century, according to the Central-European dating) Dolní Chabry was on the edge of important trade route from Prague to the northern part of the territory. Various fragments of relief decorated terracotta tiles which were found during archaeological research in Dolní Chabry in Prague were a part of the floor in an Early Romanesque rotunda. This archaeological research was induced by the planned reconstruction of the present church and the entire complex in 1973. A comprehensive study of the archaeological area in the years 19731975 gradually documented the fragments of the Romanesque construction phase of the sacral building. The foundations of the presbytery and tribune of the rotunda were uncovered in the interior of the church and were dated to the third quarter of the $12^{\text {th }}$ century. The most important findings of this research were the terracotta tiles, which formed the floor of the rotunda. These tiles have some similar motives to those of the terracotta relief tiles from the Saint Maurice Monastery in Bakonybél (Hungary), which are dated to the $11^{\text {th }}$ century [1]. The historical terrain, with the floor tiles, was partly damaged by graves because the church was used as a burial site until the $18^{\text {th }}$ century. Part of the floor was excavated in-situ and restored. The restored part is now housed in the City of Prague Museum (Figure 1). [1-2]

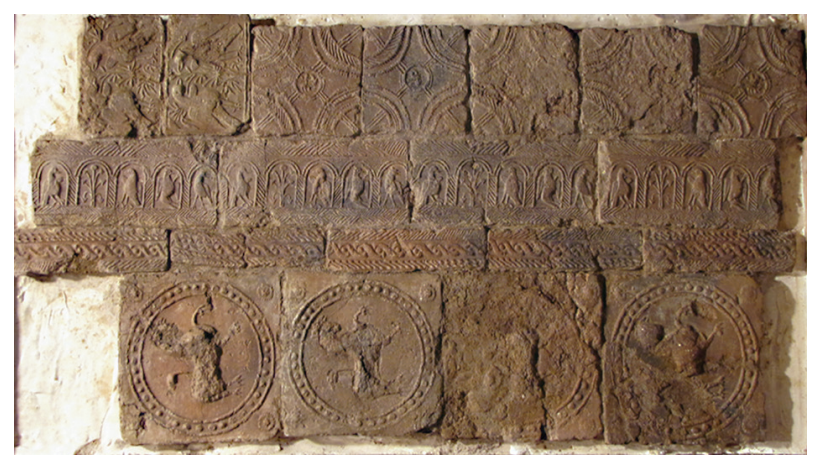

Figure 1. Partial restoration of the terracotta floor (photo M. Tryml). 
Historical ceramic tiles were usually produced from natural raw materials and so they mainly contained quartz, feldspars, micas and sometimes residua of carbonates. Ceramic bodies of historical tiles have been mostly investigated by X-ray fluorescence (XRF), X-ray diffraction (XRD), Simultaneous thermal analysis (STA) and Optical microscopy (OM) methods. These techniques of investigation, together with Infrared spectroscopy (IR) and Scanning electron microscopy (SEM), are useful characterisation methods used to define the chemical and mineralogical composition, to identify the clay minerals and the microstructure of the surface decoration and of the sherd material itself. Clay minerals were usually present in the form of reactive non-crystalline phases (meta-clays) [3-6]. These unstable meta-clays fired at temperatures below $1000^{\circ} \mathrm{C}$ can partially react with environmental moisture and rehydroxylate to the structures close to that of the original clays [7]. It is supposed that hydroxyl bonds which exist before firing are partially restored during the process of irreversible moisture expansion [8]. Environmental moisture is gradually incorporated to amorphous (non-crystalline) or inhomogeneous glassy phases which were formed during firing at relatively low temperatures [9-10]. The composition of the raw materials, firing conditions, mineralogical composition, porosity and, partially, the way of dealing with the product could influence the rehydroxylation process of such ceramic artefacts. Natural rehydroxylation can be simulated in a laboratory by using hydrothermal conditions in an autoclave [4]. The process of long term moisture expansion of a freshly fired ceramic body is the basis of moisture expansion kinetics in fired clay ceramics $[8,11]$ and is principal to the Rehydroxylation (RHX) dating method.

The consideration regarding the use of local raw materials is based on historical sources, geological maps or, if needed, samples of expected raw materials which have been taken for analyses. In many parts of Prague, ceramic raw materials have been extracted in the past $[12,13]$. Brick materials were mined in Dolní Chabry $[12,14-15]$. The premises were subsequently landfilled with municipal waste and are currently being reclaimed. Following published surveys [12, 15-16] and map views, it can be said [17] that the surroundings were rich in extensive quaternary loess and loess loam. The rocky subsoil is predominantly adjacent to the Barrandian Upper Proterozoic period, with the occurrence of graywacke, silt loam and silty slate. There are solitary intrusions of tuff and quartz porphyry directly located in the village near the church.

The main aim of this work was to evaluate the microstructure of the ceramic bodies and surface decorations, and on the basis of the identified mineralogical components of the ceramic body, to consider the use of local raw materials for the preparation of the collection of relief ceramic tiles. Furthermore, the aim was to identify the clay minerals using hydrothermal treatment and apply the Rehydroxylation dating method to the evaluated tiles. These historical tiles were also dated by archaeologists, so that we could verify the RHX dating method.

\section{EXPERIMENTAL}

Description of the tiles

Over 500 fragments of tiles were collected during the archaeological investigation of an Early Romanesque rotunda in Dolní Chabry. Individual rectangular and square shape tiles were decorated with a combination of figural, floral and geometric elements. The centre of each tile is adorned with a figural scene surrounded by ornamental motives around the edge. The tiles were divided into nineteen different types according to the relief scenes. A few of the scenes are similar to those previously used such as a griffin, lion or sphinx. The griffin, lion and sphinx motives of ancient origin were often used in Christian art. The relief decoration with a sphinx appeared more systematically in Italy in the $11^{\text {th }}$ century (e.g., wood carving in Terracina, stone bishop's throne in Canossa Castle). Iconography of animal figures on tiles, as well as ornamentation of the architectural elements of German churches (e.g., the Regensburg Cathedral), was inspired by Italian decoration. The extension of the themes of the Italian provinces was primarily due to expanding trade and routes e.g., via Brenner Pass in the Romanesque period. However, most of these relief scenes were unique, for example, birds surrounding a tree (i.e., The Tree of Life with peacocks), Daniel in the lions' den or Emperor Nero [2]. The figural scene of Emperor Nero was inspired by busts of Holy Roman Emperors on coins. The overall decor of the floor was divided into several fields by a bordure (e.g., knotwork tiles).

\section{Preparation of samples and methods of chacterisation}

The samples, for the evaluation of the microstructure of the ceramic bodies and decorative layers, were taken from different tiles from the terracotta floor. The chemical composition of a group of 50 tile samples was evaluated. Six representative samples were chosen. Figure 2 shows the fragments of the tiles that were used for appropriate analyses and the typology of the respective tiles. Six samples of the ceramic bodies from the fragments of five different tiles $(1,29,122,1249$ and 846) and two samples with different colouring separated from tile 846 - light edge part (846S) and dark central part (846T) were analysed (Figure 3). The samples were ground in an agate mortar to form fine powders, well dried at $105^{\circ} \mathrm{C}$ and were used for the X-ray fluorescence analysis (XRF). Fine fractions $(\leq 0.06 \mathrm{~mm})$ of the samples were subsequently used for the X-ray diffraction analysis 


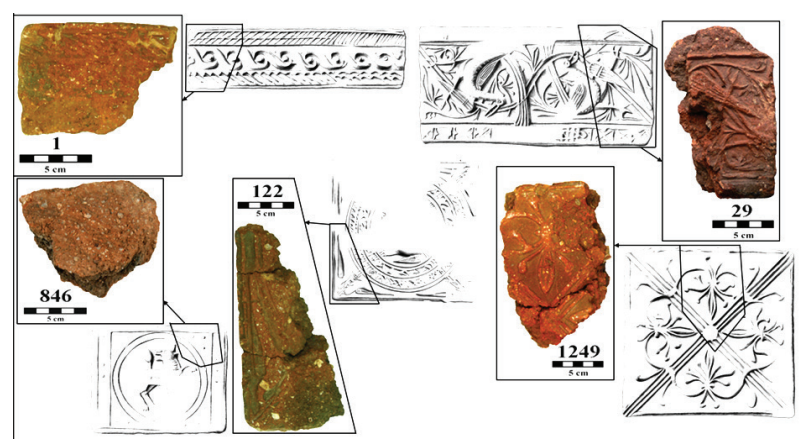

Figure 2. Photodocumentation of the studied fragments and the typology of the appropriate tiles (photo M. Kavanová, drawing archives of the National Heritage Institute).

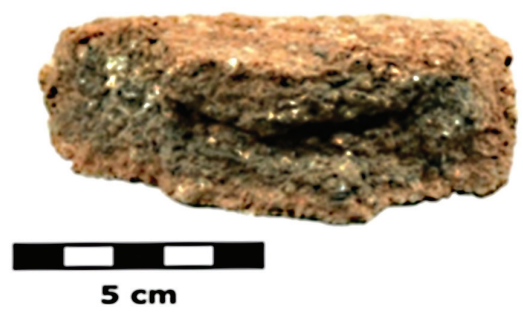

Figure 3. Fragment of tile 846.

(XRD) and a simultaneous thermal analysis (DTA-TG). A microscopic evaluation by optical microscopy (OM) was carried out on thin sections and a small rectangular fragment (almost the same volume and weight, ca. $12 \mathrm{~g}$ ) of each tile was used for the determination of the weight increase due to humidity.

\section{Instrumentation}

The chemical composition of the dried powder samples was determined by $\mathrm{X}$-ray fluorescence analysis using an ARL $9400 \mathrm{XP}$ sequential WD-XRF spectrometer equipped with an $\mathrm{Rh}$ anode end-window X-ray tube type $4 \mathrm{GN}$ fitted with a $50 \mu \mathrm{m}$ Be window. All peak intensity data was collected by the WinXRF software in a vacuum. The generator settings-collimatorcrystal-detector combinations were optimised for all 82 measured elements with a powder analysis time of $6 \mathrm{~s}$ per element. The obtained data was evaluated by the standardless software Uniquant 4 . The analysed powders were pressed into pellets about $5 \mathrm{~mm}$ thick with a diameter of $40 \mathrm{~mm}$ without any binding agent and covered with a $4 \mu \mathrm{m}$ supporting polypropylene (PP) film. The time of the measurement was about $15 \mathrm{~min}$. A statistical method of variation, called a principal component analysis (PCA) was used to identify patterns in the values gained by the XRF analysis. The principal component analysis is a useful technique to express the datasets in order to emphasise their systematic classification. The values of the chemical composition of the ceramic bodies and fine fractions of tile 846 were used for the calculation of the "normative minerals" by the MINLITH programme [18]. The term "normative minerals" is used for the calculated mineral standards and is different from the real mineralogical composition of the raw materials $[18,19]$. Although the programme was designed for sedimentary rocks, it provides a preview of the raw material composition of the evaluated ceramics.

The mineralogical composition of the powder samples was identified by Optical microscopy (OM) using an optical microscope Olympus BX60 and BX51 and by X-ray diffraction analysis (XRD). X-ray powder diffraction data was collected at room temperature with an $X^{`}$ Pert PRO $\theta-\theta$ powder diffractometer with parafocusing Bragg-Brentano geometry using $\mathrm{CuK} \alpha$ radiation $(\lambda=1.5418 \AA, U=40 \mathrm{kV}, I=30 \mathrm{~mA})$. The data was scanned with an ultrafast detector $\mathrm{X}^{\circ}$ Celerator over the angular range $5-60^{\circ}(2 \theta)$ with a step size of $0.0167^{\circ}(2 \theta)$ and a counting time of 20.32 s step- 1 . Data evaluation was performed in the software package HighScore Plus 3.0e.

The thermal behaviour was studied by simultaneous differential thermal analysis and thermogravimetry (DTA-TG) - Linseis STA PT1600/1750 ${ }^{\circ} \mathrm{C}$ HiRes using $50 \pm 0.04 \mathrm{mg}$ of a sample in a Pt crucible and a heating rate of $10^{\circ} \mathrm{C} \cdot \mathrm{min}^{-1}$ in the temperature range of $25-1000^{\circ} \mathrm{C}$ in helium flow. The gas release $\left(\mathrm{H}_{2} \mathrm{O}\right.$ and $\mathrm{CO}_{2}$ ) was measured by a Pfeiffer Vacuum OmniStarTM GSD320 in the range of 300 AMU. The samples were also exposed to hydrothermal conditions to simulate an accelerated ageing process. The hydrothermal conditions were realised in Teflon lined autoclaves at $230^{\circ} \mathrm{C}$ $(2.77 \mathrm{MPa})$ for 100 hours with a solid/solution ratio $1 \mathrm{~g}$ sample/20 $\mathrm{ml}$ water and used for the identification of the clay minerals in the samples [4, 20-21].

\section{Rehydroxylation (RHX) dating method}

The RHX method has been presented [22-23] as a suitable mathematical model describing the rehydroxylation process which can be used to date ceramic artefacts. This method relies on the ability of the ceramic body containing unstable non-crystalline residues of clay minerals to rebind water in a two-step process of rehydration $\left(1^{\text {st }}\right.$ stage $)$ and rehydroxylation $\left(2^{\text {nd }}\right.$ stage). The reaction of the ceramic body with the water vapour could be observed on the reheated (to a suitable high temperature) ceramic object exposed to stable conditions (relative humidity and temperature). The initial, short $1^{\text {st }}$ stage, which lasts only a few hours after reheating, is much faster that the second one and the reheated ceramic object regains water by rehydration. In this relatively quick first stage of mass gain, the absorption of water molecules into the surface and into the open porous system of the ceramics occurs. 
During the following long-term $2^{\text {nd }}$ stage, hydroxyl water is slowly incorporated into the clay minerals and the ceramic artefacts undergo the rehydroxylation process. The rehydroxylation (RHX) process was defined by the kinetic equation of (time) $)^{1 / 4}$ power law [22]. The principle of the rehydroxylation dating method is the determination of the initial mass of a sample, which is the sum of the sample mass after firing and the mass of water bonded to the structure of a ceramic artefact during its deposition. By extrapolating the data obtained from the second stage of the RHX method, we can calculate the estimated age of a ceramic artefact. This method was proposed as self-calibrating without any standardisation and, thus, neglects the influence of firing temperature or mineralogical composition as demonstrated in Wilson et al. [23]. The futher testing of this method on real samples showed the need for further investigation, especially in connection with the mineralogical composition and storage conditions [24-30].

The aging process based on the mass increase under the controlled conditions was monitored on small fragments of the archaeological tiles. These samples were dried at $105 \pm 2{ }^{\circ} \mathrm{C}$ to a constant weight (usually for 24 hours) in the BMT Venticell 55 laboratory and weighed using an AND GR 200 analytical balance, with a precision of $0.1 \mathrm{mg}$. Then the samples were reheated in a CLASIC laboratory furnace at $650^{\circ} \mathrm{C}$ for 12 hours

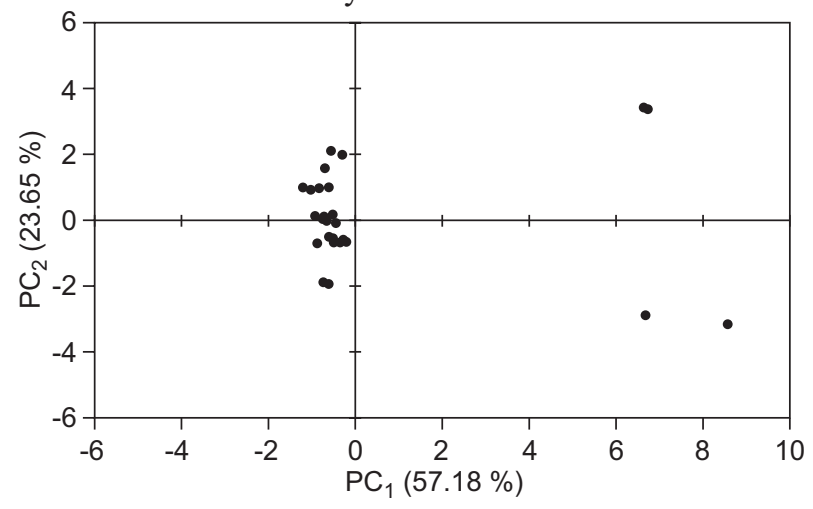

Figure 4. The principal component biplot of the XRF data for the analysed ceramic tiles: the principal component biplot showing the distribution of the tile samples into groups. to release all chemically bonded water [11, 24-25]. The reheated samples were placed on a measuring cell of the analytical balance in an enclosed measuring box with a stable controlled temperature $\left(19 \pm 1^{\circ} \mathrm{C}\right)$ and relative humidity $(30 \pm 2 \%)$. The reheating temperature of $650^{\circ} \mathrm{C}$ and time of 12 hours were selected after several experiments which confirmed that lower temperatures and shorter times are not sufficient enough to complete the removal of the bonded water.

\section{RESULTS AND DISCUSSION}

Chemical and mineralogical composition

The chemical compositions of the archaeological samples are presented in the form of main components (Table 1, Figure 4). The principal component biplot of the XRF data obtained for the 50 analysed ceramic tile fragments is presented in Figure 4. It is evident that all the tile samples except sample 846 are similar and very small differences are probably the result of some inhomogeneity in the the ceramic historical materials (e.g., when mixing and homogenising the raw materials). The samples of tile 846 are slightly different from the other samples by a smaller content of colouring oxides and silicon oxide and a higher content of aluminium oxide. In this case, the first and second principal component (PC1 and PC2) was responsible for $80.83 \%$ of the total variance in the datasets. The values of the chemical composition were used for the calculation of the main normative minerals (Table 2), which indicate the theoretical mineralogical composition of the raw materials.

The mineralogical compositions of the archaeological ceramics are very similar (Figure 5). The archaeological ceramics contained: quartz, micas (muscovite and sericite), and feldspars (orthoclase, microcline and plagioclase), as main mineral phases. The presence of clay minerals was studied using hydrothermally treated samples. A comparison of the XRD patterns of the original $(846 \mathrm{~S}, 846 \mathrm{~T})$ and hydrothermally treated samples $(846 \mathrm{~S}$ after HT and

Table 1. Semi-quantitative chemical composition of the samples determined by XRF.

\begin{tabular}{lccccccccc}
\hline \multirow{2}{*}{ Samples } & \multicolumn{7}{c}{ Content (wt. \%) } \\
\cline { 2 - 10 } & $\mathrm{SiO}_{2}$ & $\mathrm{Al}_{2} \mathrm{O}_{3}$ & $\mathrm{Fe}_{2} \mathrm{O}_{3}$ & $\mathrm{TiO}_{2}$ & $\mathrm{CaO}$ & $\mathrm{MgO}$ & $\mathrm{K}_{2} \mathrm{O}$ & $\mathrm{Na}_{2} \mathrm{O}$ & $\mathrm{Others}^{2}$ \\
\hline 1 & 63 & 21 & 6 & 1.0 & 0.9 & 1.5 & 4 & 0.9 & 1.7 \\
29 & 64 & 21 & 6 & 1.0 & 1.1 & 1.6 & 3.7 & 0.9 & 0.7 \\
122 & 64 & 20 & 6 & 1.0 & 1.2 & 1.5 & 4.5 & 1.2 & 0.6 \\
$846 \mathrm{~S}$ & 61 & 24 & 3.6 & 0.6 & 1.5 & 1.6 & 5 & 1.8 & 0.9 \\
$846 \mathrm{~T}$ & 61 & 24 & 3.6 & 0.6 & 1.4 & 1.6 & 5 & 1.8 & 1 \\
1249 & 64 & 21 & 6 & 1.0 & 0.9 & 1.6 & 4 & 1.2 & 0.3 \\
846S fine fraction & 58 & 26 & 5 & 0.8 & 2.5 & 2 & 3.5 & 1.6 & 0.6 \\
846T fine fraction & 58 & 27 & 5 & 0.8 & 1.4 & 2.1 & 3.4 & 1.5 & 0.8 \\
\hline
\end{tabular}

Others $-\mathrm{P}_{2} \mathrm{O}_{5} ; \mathrm{V}_{2} \mathrm{O}_{5} ; \mathrm{MnO} ; \mathrm{Rb}_{2} \mathrm{O} ; \mathrm{SrO} ; \mathrm{BaO}$ 
Table 2. Main normative mineral composition of the tile samples calculated from the chemical composition by the MINLITH programme.

\begin{tabular}{lrrcccr}
\hline \multirow{2}{*}{ Samples } & \multicolumn{5}{c}{ Main normative minerals (wt. \%) } \\
\cline { 2 - 7 } & \multicolumn{1}{c}{ Q } & \multicolumn{1}{c}{ Fsp } & Ill & Kn & Mm & Others \\
\hline 1 & 25.29 & 3.67 & 41.39 & 5.05 & 17.02 & 7.58 \\
29 & 25.05 & 2.41 & 37.80 & 5.66 & 21.11 & 7.97 \\
122 & 29.26 & 13.60 & 46.60 & 0 & 0 & 10.54 \\
$846 \mathrm{~S}$ & 16.37 & 12.55 & 51.51 & 0.75 & 13.96 & 4.86 \\
$846 \mathrm{~T}$ & 16.40 & 12.58 & 51.61 & 0.75 & 13.99 & 4.67 \\
1249 & 25.85 & 4.59 & 41.17 & 0.52 & 19.57 & 8.30 \\
846S fine fraction & 6.90 & 5.51 & 34.52 & 10.55 & 31.51 & 11.01 \\
846T fine fraction & 7.17 & 4.60 & 34.20 & 14.21 & 32.68 & 7.14 \\
\hline
\end{tabular}

Q-Quartz; Fsp-Feldspars; Ill - Illite; Kn-Kaolinite; Mm-Montmorillonite;

Others - Apatite, Carbonates, Gypsum, Hematite, Pyrolusite, Rutile

$846 \mathrm{~T}$ after HT) in a small angle range $\left(2-15^{\circ} 2\right.$ Theta $)$ was provided (Figure 6). The XRD patterns of both hydrothermally treated samples show a pronounced broad peak at about $5-8^{\circ} 2$ Theta which was not detected in the original samples. This peak can be attributed to montmorillonite which rehydroxylated from its metaform. The XRD pattern of $846 \mathrm{~S}$ after HT also shows a small peak at about $12.4^{\circ} 2$ Theta which can be attributed to the rehydroxylated kaolinite.

\section{Thermal analysis and gas evolution}

Figure 7 shows the results of the thermal analysis (TG, DTA, release of $\mathrm{H}_{2} \mathrm{O}$ and $\mathrm{CO}_{2}$ ) of the archaeological ceramics. The samples, before the hydrothermal treatment (Figure 7a, 7c), show the release of a small amount of water in the interval $100-600^{\circ} \mathrm{C}$ related to the dehydration and dehydroxylation of the meta-clays.

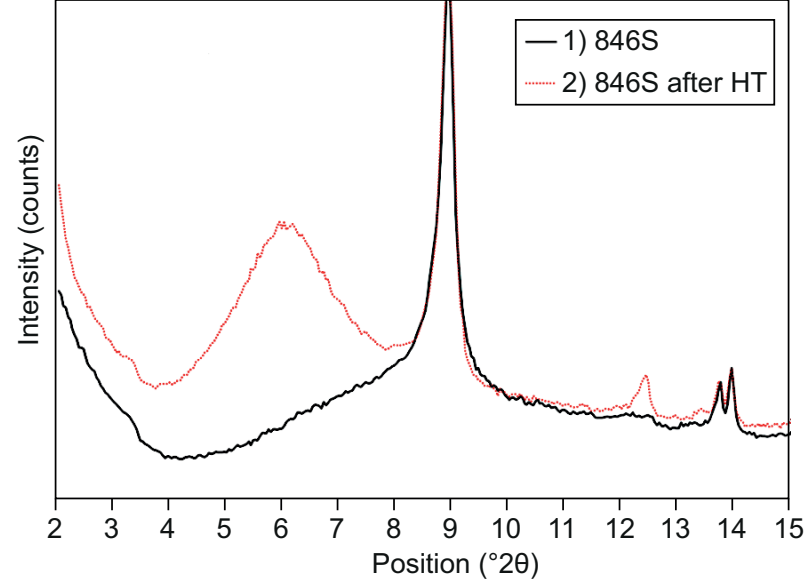

a)

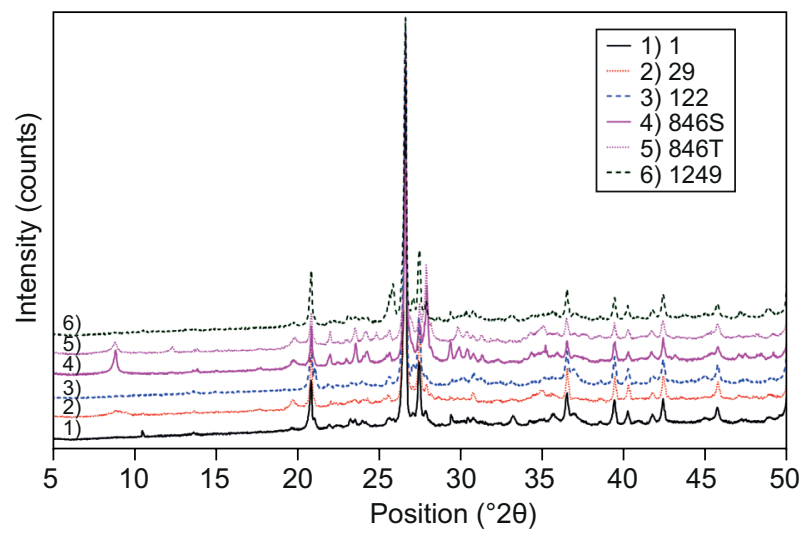

Figure 5. The XRD patterns of the ceramic bodies of archaeological tiles; the patterns of the individual samples are shifted and arranged chronologically from bottom to top (from sample 1 to sample 1249).

A more pronounced release of water was registered for the hydrothermally treated samples (Figure 7b, 7d) at $100-250^{\circ} \mathrm{C}$ related to the loss of the remaining loosely bound water and to the dehydration of the clay minerals, especially montmorillonite characterised by a double peak at the $\mathrm{MS}-\mathrm{H}_{2} \mathrm{O}$ curve. Another endothermic effect was registered at $400-700^{\circ} \mathrm{C}$ related to the dehydroxylation of the meta-clays (montmorillonite and partially kaolinite) [31]. A similar course of the dehydroxylation of the meta-clays with a lower intensity of the peaks showed up in samples 29 and 1249, the curves of samples 29 and 122 showed only slight differences. The DTA curves of all the samples show small endothermic peaks related to the transformation from $\beta$-quartz to $\alpha$-quartz $\left(\sim 570^{\circ} \mathrm{C}\right)$, then an endothermic peak related to mica dehydroxylation $\left(\sim 880^{\circ} \mathrm{C}\right)$ and an exothermic peak, which is related to the crystallisation of the spinel structure $\left(\sim 940^{\circ} \mathrm{C}\right)$. The green curve of the $\mathrm{CO}_{2}$ release indicates presence of organic substances. Dark colouring

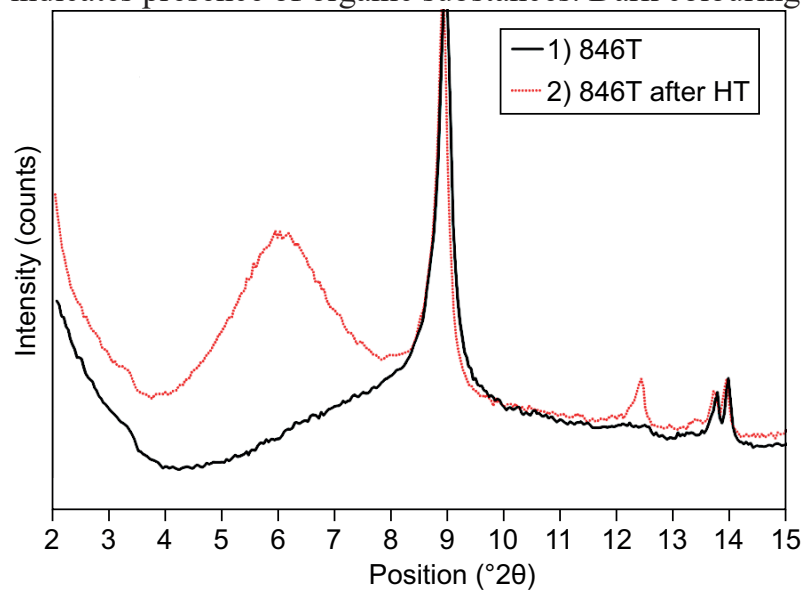

b)

Figure 6. Detail of the XRD patterns of the fine fractions $(\leq 0.06 \mathrm{~mm})$ of sample 846 : a) the XRD patterns of the light edge part of the ceramic body and b) the XRD patterns of the dark central part of the ceramic body; solid lines = fine fractions of samples, dotted lines $=$ fine fractions of samples after hydrothermal treatment $(\mathrm{HT})$ at $230^{\circ} \mathrm{C}$ for 100 hours. 


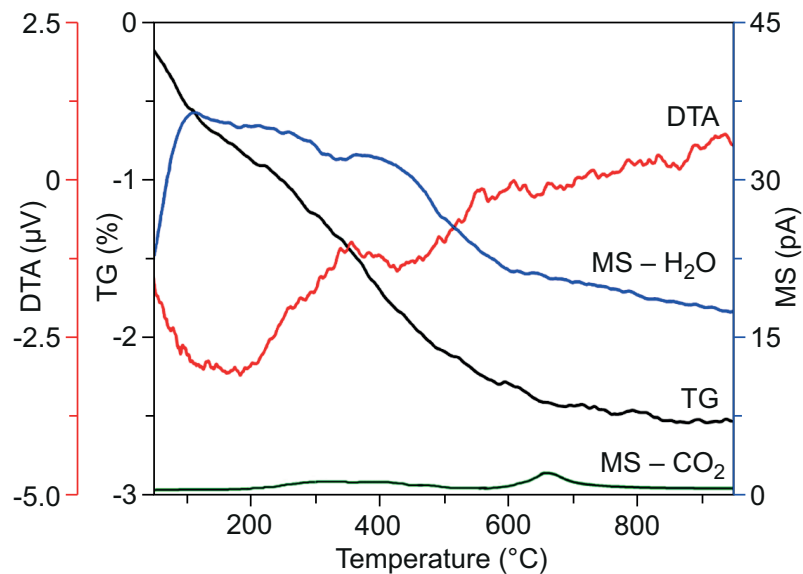

a)

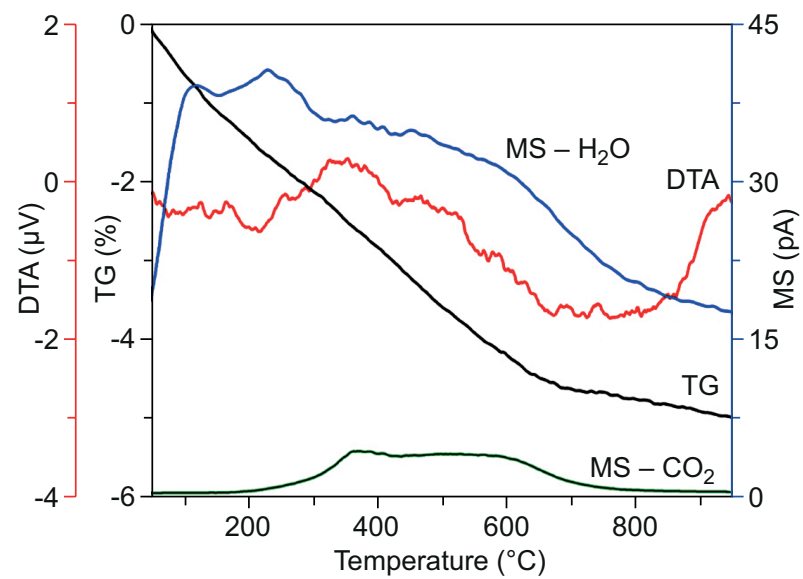

c)

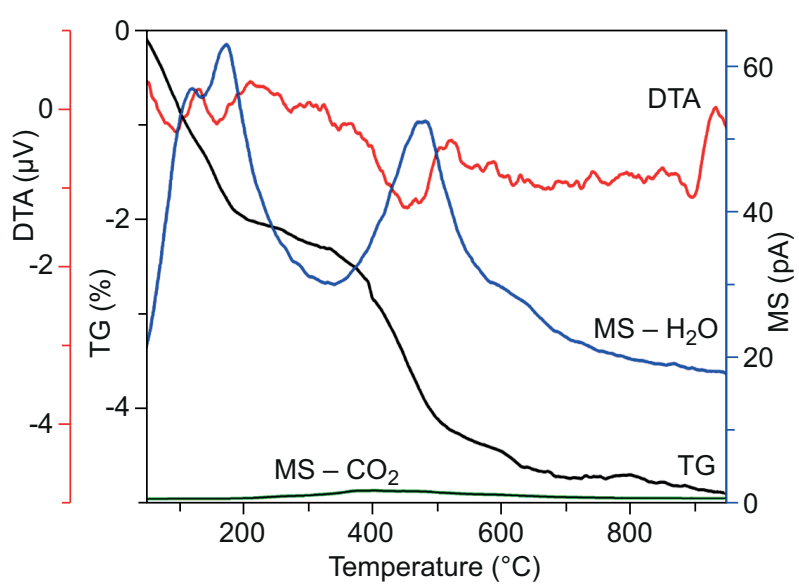

b)

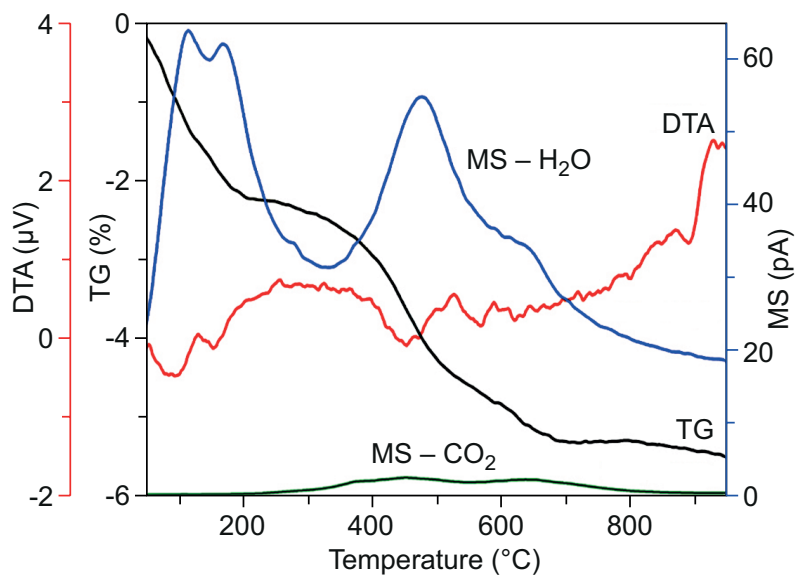

d)

Figure 7. Representative thermal analysis (TG, DTA) curves and gas evolution (MS) curves of the fine clay components of the archaeological tile 846: a) sample $846 \mathrm{~S}$ before hydrothermal treatment, b) sample $846 \mathrm{~S}$ after hydrothermal treatment $\mathrm{HT}\left(230^{\circ} \mathrm{C}\right.$ and 100 hours $)$, c) sample $846 \mathrm{~T}$ before hydrothermal treatment and d) sample $846 \mathrm{~T}$ after hydrothermal treatment $\mathrm{HT}\left(230^{\circ} \mathrm{C}\right.$ and 100 hours).

of the central sample (846T) was probably caused by the presence of amorphous $\mathrm{C}$ and local reducing conditions inside of the tile during firing. The probable source of amorphous $\mathrm{C}$ is an organic component, as proven by a broad peak at the $\mathrm{MS}-\mathrm{CO}_{2}$ curve in the temperature interval $200-700^{\circ} \mathrm{C}$ shown in Figure $7 \mathrm{c}, 7 \mathrm{~d}$.

\section{Microscopic evaluation}

Thin sections of the archaeological samples were observed by an optical microscope in plain and crossed polarised light. The samples showed a not very homogeneous hematite rich clay matrix characterised by various easily distinguishable inclusions of irregular shape and elongated pores, see Figure 8a. Macroelongated pores preferably aligned in a horizontal direction demonstrate that the surface layer of the tiles rebounds (Figure 8b). This figure proves that the surface layers were subsequently applied on the prepared tiles.
Feldspar grains and polyminerallic inclusions composed of quartz and feldspar crystals were observed in the thin sections of all the archaeological samples. Typical rock fragments of a large subrounded grain of a thermally altered feldspar and the quartz (is interstitial to feldspar), and some flakes of biotite mica are visible in the microphotograph of a thin section of sample 1 (Figure 8c). Some polycrystalline quartz grains showed undulose extinction $(8 \mathrm{a}, 8 \mathrm{c}, 8 \mathrm{f})$. This is a sign that the rock has been strained and is a common feature of much quartz in igneous, sedimentary and metamorphic rocks [32]. Large fragments of granite in sample 846 (Figure 8d) were composed of quartz, mica and two feldspars - alkali feldspar and plagioclase, which was present in a much lower portion than the alkali feldspar. The plagioclases are more altered than the alkali feldspar. The abundant high birefringent scaly flakes in plagioclas are sericite mica, fine-grained sericite mica could be the product of the metamorphosis of the 


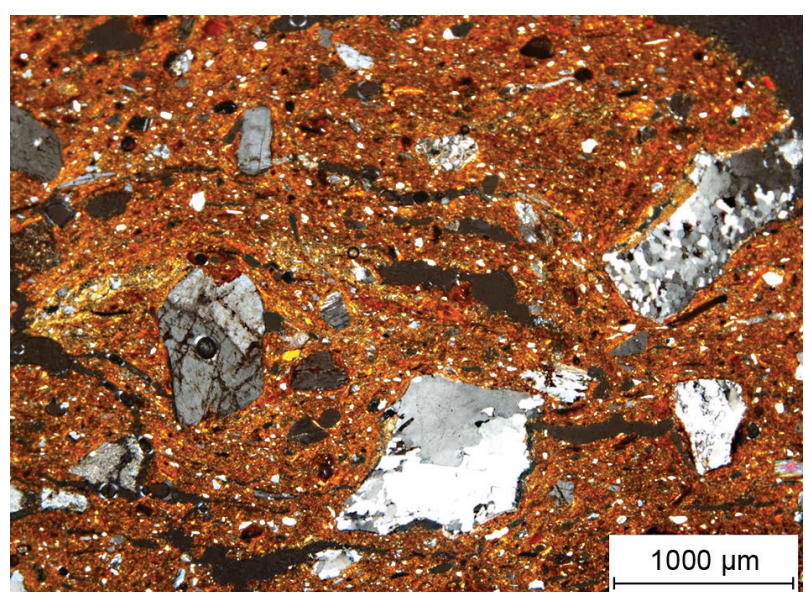

Figure 8a. Microphotograph of a thin section of the ceramic bodies of sample 1 shows a not very homogeneous hematite rich clay matrix characterised by various easily distinguishable inclusions of irregular shape and elongated pores, the large angular inclusions, visible in this sample, derive primarily from igneous rock that was probably crushed and added as a temper, quartz grains showed undulose extinction.

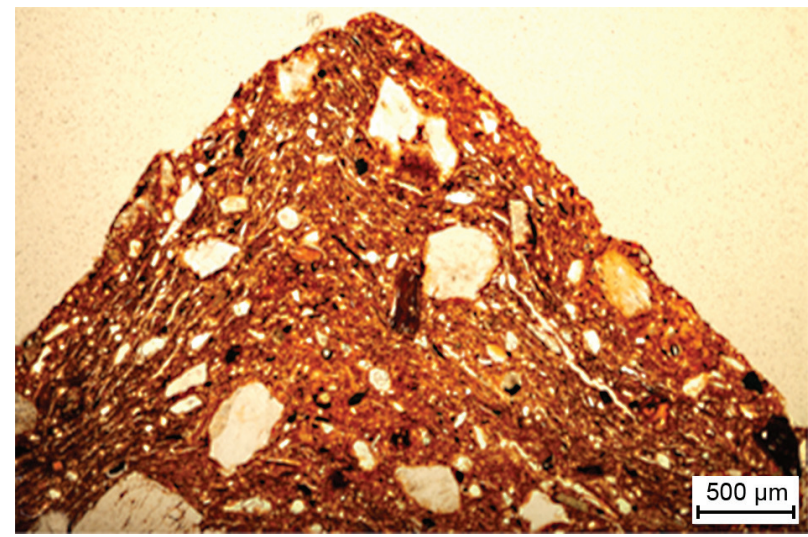

Figure $8 \mathrm{~b}$. Microphotograph of the surface layer of tile 122 shows macro-elongated pores preferably aligned in the horizontal direction, the photo proves that the surface layer of all the samples rebounds.

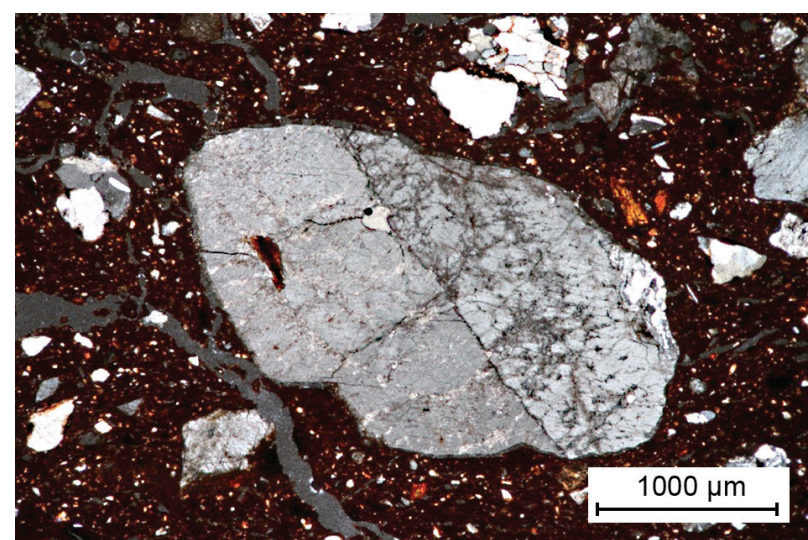

Figure 8c. Microphotograph of a thin section of sample 1, typical rock fragment of a large subrounded grain of a thermally altered feldspar, quartz and some flakes of biotite mica are interstitial to the feldspar. original rock [33]. Most of the alkali feldspar crystals show patches, of cross hatched twinning (sometimes only in the cores of the crystals), whereas the albite shows lamellar twinning [32], which were observed in the central part of the rock fragment and the white area on the left is quartz (Figure 8e). Potassium-rich feldspar with irregular intergrowths of sodic feldspar forming a microperthitic texture which is typical for granites [33] was found in the other thin sections of sample 846, myrmekitic intergrowths (rod-like inclusions of quartz within a plagioclase grain) was rarely identified. The small olive-green zoning tourmaline grains, which are characteristic for granitic pegmatites, were randomly found in sample 846 (Figure 8f). However, pleochroic amphiboles showing $120^{\circ}$ cleavage, which are minerals of either metamorphic or igneous rocks, were observed in all of the thin sections of archaeological tiles except sample 846 (Figure 8g).

The microscopic evaluation of the thin sections of the five archaeological tiles confirmed that their mineralogical composition is very similar. Only sample 846

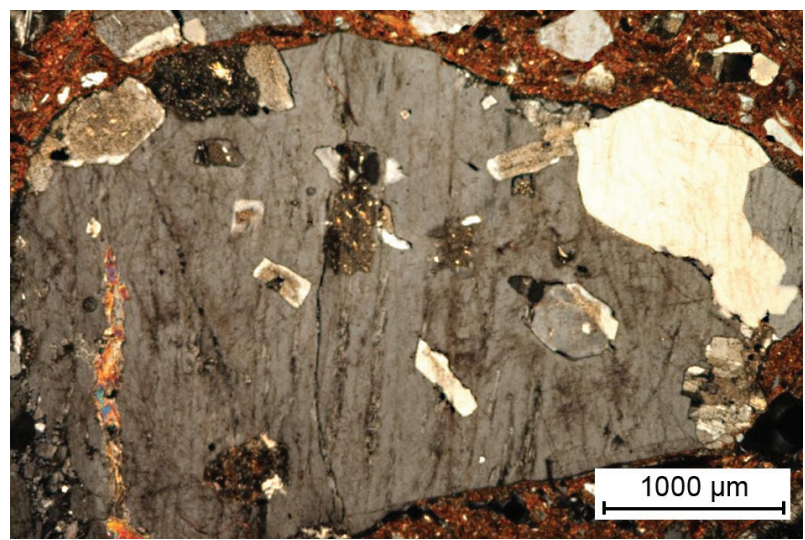

Figure 8d. Microphotograph of a thin section of sample 846, large fragments of the rocks are composed of two feldspars alkali feldspar and plagioclase and quartz, the abundant high bire-fringent scaly flakes in the plagioclase are sericite mica.

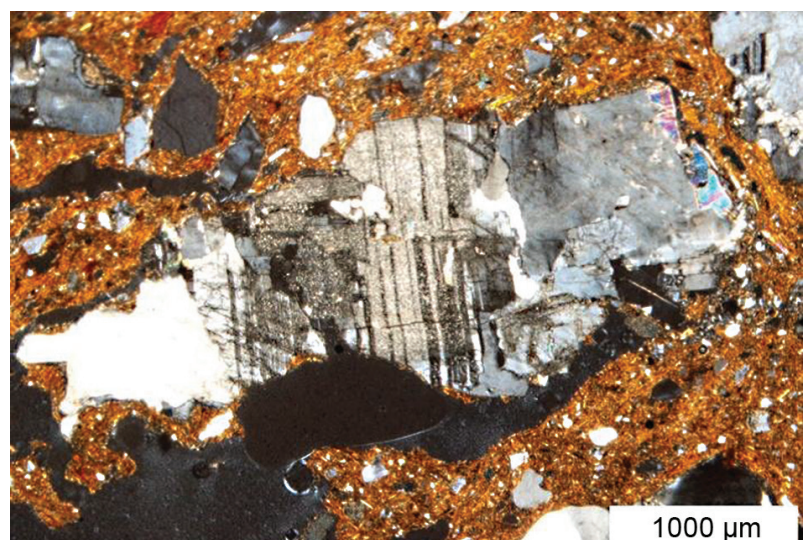

Figure 8e. Microphotograph of a thin section of sample 846, in central part of fragment of rock is albite showed typical plagioclase lamellar twinning, the white area of the left is quartz. 


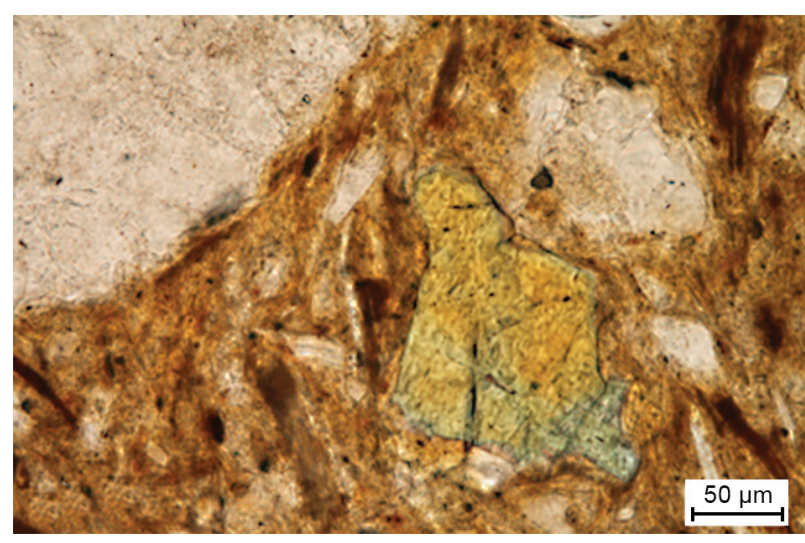

Figure 8f. Microphotograph of a thin section of sample 846 and presents an irregular small grain of tourmaline.

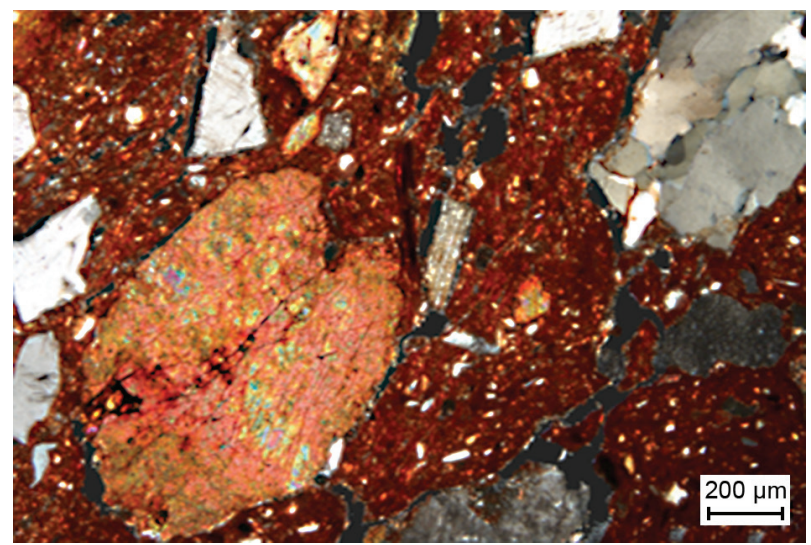

Figure 8g. Microphotograph of the oval amphibole grain of a relatively large size typical for igneous rocks is shown in the thin section of sample 1249 .

slightly differs in a lower content of amphibole and with the presence of tourmaline. These inclusions are mostly of metamorphic or igneous (especially granite) origin.

The results of the mineralogical evaluation are consistent with published data [16]. Sample 846, which was slightly different from the rest of the samples (and, therefore, was examined), also contained fragments of rocks which are not present in the site (granite). This sample did not confirm the possibility of local provenance also. The sample matrix had a low $\mathrm{CaO}$ content $(0.3-1.4$ wt. \%), only in the case of the light part of sample 846 , the content was higher (2.5 wt. \%). For Central Bohemia, the value of $5-10$ wt. $\% \mathrm{CaO}$ is reported for loess [34], so neither was this plastic raw material local.

\section{Rehydroxylation (RHX) dating}

The samples were prepared from five relief decorated fragments of archaeological tiles for the determination of weight increase in the period of 3 - 5 days. Mass gain due to the rebinding of water to the ceramic system of the samples was observed and used for the calculation of the

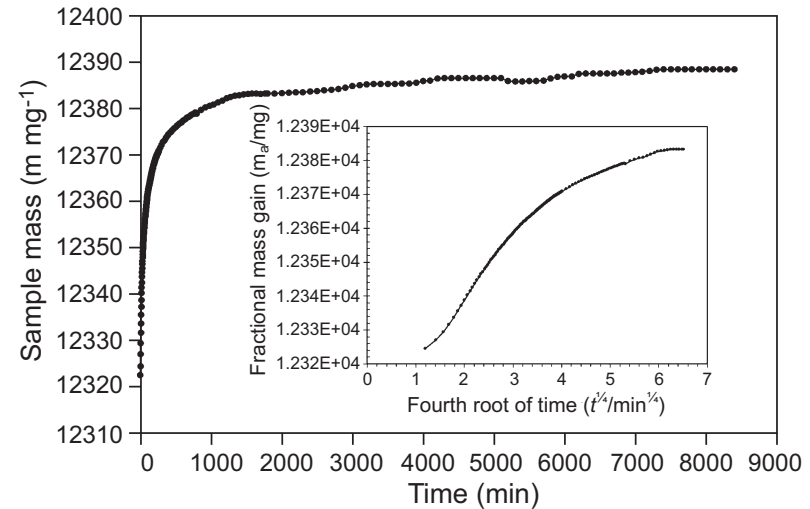

Figure 9. Rehydroxylation kinetics of the reheated sample of tile 846 during rehydroxylation (sample mass $m$ versus time $t$ and fractional mass gain versus the fourth root of time $t^{1 / 4}$ dependence).

tiles' age. The calculated age is obtained by extrapolating the collected data to the initial mass of the sample.

Figure 9 shows the rehydroxylation kinetics of a selected tile (reheated tile 846) as a mass versus time and fractional mass gain versus the fourth root of time $t^{1 / 4}$ dependence. It is evident that the aging process proceeds in two stages. The linear dependence of the experimental mass gain on the fourth root of time of the $2^{\text {nd }}$ stage of the RHX method is also presented in the figure.

The initial mass and experimental mass gain during exposition of the reheated samples in the controlled conditions (relative humidity, temperature) were used for the calculation of the approximate age of the tiles by the RHX dating method (Figure 10). The adequate age of the tile sample was determined using the fit of a linear trendline. The high R-squared value (correlation coefficient) revealed the estimated values of the $2^{\text {nd }}$ stage, which were used for subsequent calculations. The estimated age was acquired at $856 \pm 24.5$ years (with a standard deviation of 5 measurements) which corresponds to the assumptions

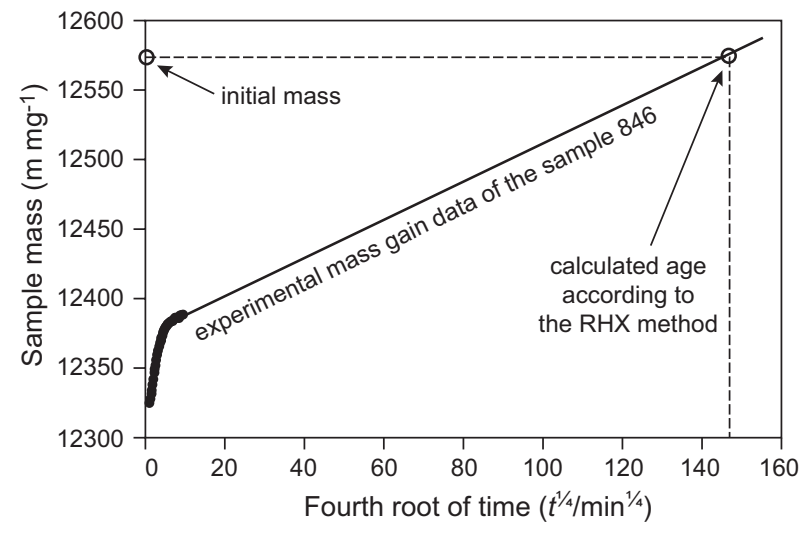

Figure 10. Rehydroxylation kinetics of sample 846 by the RHX dating method. 
of the archaeologists. Using all the $2^{\text {nd }}$ phase values (low R-squared value) would shift the dating into a modern age. Archaeologists following the iconography and excavation conditions estimated that the floor tiles were produced and installed in the rotunda during the $12^{\text {th }}$ century.

\section{CONCLUSION}

The studied historical ceramic tiles showed small differences in chemical and mineralogical composition only, which were caused by the inhomogeneity of the raw material and by the variable firing temperature. Clay minerals such as montmorillonite and kaolinite were identified in the raw materials using a hydrothermal treatment. The identified minerals and rocks exclude the use of local raw materials; the tiles were imported. The use of the RHX dating method for these types of materials is dependent on controlled conditions during the mass gain process. However, it was found that the calculated age is related to that estimated by archaeologists when we used linear trendline fitting with the highest value of the correlation coefficient. The shape of the pores indicates that the tiles were produced by ramming them into moulds. The surface relief decorated layer was formed by the fine fraction of the matrix with smaller inclusions which proves that the decorative layer was applied subsequently.

\section{Acknowledgements}

Financial support from specific university research (MSMT No. 20/2015 and MSMT No 20-SVV/2016) is gratefully acknowledged.

\section{REFERENCES}

1. Merhautová, A. (1988). Skromné umění. Ostrovská zdobená keramika. 1st ed. Academia. pp. 138.

2. Dragoun Z., Tryml, M., Mjartan, J. (2010): Restaurování torz středověkých podlah z Dolních Chaber a Břevnovského kláštera - Restoration of medieval floor torsos from Dolní Chabry and Břevnov Monastery. Staletá Praha, XXVI (2), 122-129.

3. Kloužková A., Kavanová M., Kohoutková M., Zemenová Z., Dragoun Z. (2016): Identification of causes of degradation of Gothic ceramic tiles by thermal analyses. Journal of Thermal Analysis and Calorimetry, 125(3), 1311-1318. doi: 10.1007/s10973-016-5488-5

4. Kloužková A., Zemenová P., Kohoutková M., Mazač Z. (2016): Ageing of fired-clay ceramics: Comparative study of rehydroxylation processes in a kaolinitic raw material and moon-shaped ceramic idol from the Bronze Age. Applied Clay Science, 119(2), 358-364. doi: 10.1016/j. clay.2015.11.002

5. Quinn P.S. (2013). Ceramic Petrography - The Interpretation of Archaeological Pottery \& Related Artefacts in
Thin Section. Archaeopress, pp. 213-217.

6. Warren J. (1999). Conservation of Brick. ButterworthHeinemann, pp. 30-31.

7. Hanykýř V., Kloužková A., Bouška P., Vokáč M. (2009): Ageing of historical ceramics, Acta Geodynamica et Geomaterialia, 6(1), 59-66.

8. Zemenová P., Kloužková A., Kohoutková M., Král R. (2014): Investigation of the first and second dehydroxylation of kaolinite. Journal of Thermal Analysis and Calorimetry. 116(2), 633-639. doi: 10.1007/s10973-014-3748-9

9. Hanykýř V., Maryška M., Bouška P., Pume D. (2003): Vznik keramického střepu a jeho stárnutí - Část I. (Formation of the ceramic body and its ageing - Part I). Silika, 5-6, 130-135.

10. Hanykýř V., Kloužková A., Vokáč M. (2009). Stárnutí pórovitého keramického střepu (Ageing of porous ceramic body), in: Bouška, P., Kloužková, A.: Objemové změny pórovité keramiky (Volume changes of porous ceramics). Silis, pp. 33-43, ISBN 978-80-86821-54-2.

11. Královec J. (2010). Nevratná vlhkostní roztažnost pórovitého a cihlářského střepu (Irreversible moisture expansion of earthenware and brick body), Diploma thesis. UCT Prague.

12. Kovanda J. et al. (2001). Neživá príroda Prahy a jejího okoli, $1^{\text {st }}$ ed. Academia Praha, pp. 98. ISBN 80-7075-515-6

13. Zavřel J. et al. (2012). Pražský vrch Petřin, $2^{\text {nd }}$ ed. Paseka, pp. 29. ISBN 987-80-7432-244-0.

14. http://www.dchabry.cz/dchabry/1-O-CHABRECH/1HISTORIE-CHABER

15. Chlupáč I., Brzobohatý R., Kovanda J., Stráník Z. (2011). Geologická minulost České republiky. Academia. pp. 379. ISBN 978-80-200-1961-5

16. Vařilová Z. (2001): Surovinové zdroje a provenience románských terakotových dlaždic. Archeologické rozhledy, LIII, 515-563.

17. http://www.geology.cz/app/ciselniky/lokalizace/show map.php?mapa $=\mathrm{g} 50 \& \mathrm{y}=740400 \& \mathrm{x}=1036400 \& \mathrm{~s}=1$

18. Rosen O.M., Abbyasov A.A., Tipper J.C. (2004): MINLITH: an experience-based algorithm for estimating the likely mineralogical composition of sedimentary rocks from bulk chemical analyse, Computers \& Geoscience, 30, 647-661. doi: 10.1016/j.cageo.2004.03.011

19. Monette Y. (2013): Ore testing at the first permanent French settlement in America, 1541-1543. Searching for the origins of fire assay crucibles used at Charlesbourg-Royal (Québec, Canada). Applied Clay Science, 82, 91-100. doi: 10.1016/j.clay.2013.06.018

20. Kloužková A., Zemenová P., Kohoutková M., Kloužek J. (2013): Hydrothermal rehydroxylation of kaolinite studied by thermal analysis. Ceramics Silikáty, 57(4), 3423-3447.

21. Kavanová M. (2014). Hodnocení mikrostruktury a stárnutí střepových hmot románských dlaždic z Dolních Chaber (Evaluation of microstructure and ceramic body ageing of Romanesque tiles from Dolní Chabry), Diploma thesis. UCT Prague.

22. Wilson M.A., HoffW.D., Hall C., McKay B., Hiley A. (2003): Kinetics of Moisture Expansion in Fired Clay Ceramics: A (Time) 1/4 Law. Physical Review Letters, 90(12), 1255031-125503-4. doi: 10.1103/PhysRevLett.90.125503

23. Wilson M.A., Hamilton A., Carter M.A., Hall C. (2012): Rehydroxylation (RHX) dating of archaeological pottery. Proceedings of the Royal Society A, 468, 3476-3493. doi: 10.1098/rspa.2012.0109

24. Bowen P.K., Ranck H.J., Scarlett T.J., Drelich J.W. 
(2011): Rehydration/Rehydroxylation kinetics of reheated XIX-century Davenport (Utah) ceramics. Journal of the American Ceramic Society, 94(8), 2585-2591. doi: 10.1111/j.1551-2916.2011.04451.x

25. Kavanová M. (2012). Složení a mikrostruktura gotické keramické dlažby (Composition and microstructure of Gothic ceramic tiles), Bachelor thesis. UCT Prague.

26. Vokáč M., Kloužková A., Hanykýř V., Bouška P. E (2009): Dilatometric analysis of ceramic roof tiles for determining irreversible moisture expansion. Ceramics Silikáty, 53(4), 303-309.

27. Barrett G.T. Rehydroxylation dating of fired clays: an improved time-offset model to account for the effect of cooling on post-reheating mass gain. Journal of Archaeological Science, 40(10), 3596-3603. doi: 10.1016/j.jas. 2013.04.032

28. Le Goff M., Gallet Y. (2015): Experimental Variability in Kinetics of Moisture Expansion and Mass Gain in Ceramics. Journal of the American Ceramic Society, 98(2), 398-401. doi: 10.1111/jace.13336

29. Le Goff M., Gallet Y. (2015): Evidence for complexities in the RHX dating method. Archaeometry, 57(5), 897-910. doi: 10.1111/arcm.12137

30. Numrich, M., Kutschera W., Steier P., Sterba J. H., Golser R. (2015): On the effect of organic carbon on rehydroxylation (RHX) dating. Journal of Archaeological Science, 57, 92-97. doi: 10.1016/j.jas.2015.01.016

31. Földvári M. (2011). Handbook of thermogravimetric system of minerals and its use in geological practice. $1^{\text {st }}$ ed. Geological Institute of Hungary.

32. Yardley B. W. D., MacKenzie W. S., Guilford C. (1990). Atlas of metamorphic rocks and their texture. $1^{\text {st }}$ ed. Longman Scientific \& Technical. pp. 92-95. ISBN 978-1874545-17-0

33. Reedy C. L (2008). Thin-section Petrography of Stone and Ceramic Cultural Materials. $1^{\text {st }}$ ed. Archetype Publications. pp. 27-33.

34. Růžičková E., Růžička M., Zeman A., Kadlec J. (2003). Kvartérni klastické sedimenty České republiky, struktury a textury hlavnich getických typio. Česká geologická služba. pp. 36, 42. ISBN 80-7075-600-4 